palaeotemperatures against the background of immaturity for most of the region. The combination of optical and organic geochemical methods will provide useful parameters pertaining to the characterisation and classification of potential source rocks.

\title{
References
}

Henderson, G. 1969: Oil and gas prospects in the Cretaceous-Tertiary basin of West Greenland. Rapp. Grønlands geol. Unders. 22, $63 \mathrm{pp}$.

Müller, F. 1959: Beobachtungen über Pingos. Detailuntersuchungen in Ostgrönland und in der Kanadischen Arktis. Meddr Grønland, 153, 3, 127 pp.

Schiener, E. J. 1976: Study of organic matter in Cretaceous-Tertiary sediments, central West Greenland. Rapp. Grønlands geol. Unders. 80, 43-49.

D.L., KFA - Erdöl und Organische Geochemie, Jülich 1, Postfach 1913, D 517 West Germany.

\section{Development in petroleum exploration offshore West Greenland during 1977}

\section{Gilroy Henderson}

Four wells were drilled offshore West Greenland during the summer and early autumn of 1977 , these bringing to five the total number of wells drilled so far in this region (Table 2). Three of the wells were situated in water depths of 104 to $163 \mathrm{~m}$ on the continental shelf while the fourth, Ikermiut 1, was drilled in $447 \mathrm{~m}$ of water on the continental slope (fig. 11). All four wells were dry holes, and were plugged and abandoned immediately after completion of the drilling, all installations being cut off below the sea floor.

GGU staff were closely involved, together with other representatives from the Ministry for Greenland, in the assessment of the drilling programmes in advance of the drilling, and GGU was represented on the ministerial group that followed the progress made in each well from day to day. GGU staff paid at least two inspection visits to each of the drilling platforms. Cuttings samples, core splits and copies of all well logs were submitted to the Ministry by the operators and are currently being worked on independently by the Survey. Numerous discussions were held throughout the year with representatives of the operating companies that were drilling or had drilled wells offshore.

Four of the groups completed a total of over $2000 \mathrm{~km}$ of deep-penetration seismic surveys, which brings the total amount of new seismic lines shot since April 1975 to about $15000 \mathrm{~km}$. 
Fig. 11. Positions of the five wells drilled to date offshore West Greenland. Bathymetric contours in metres.

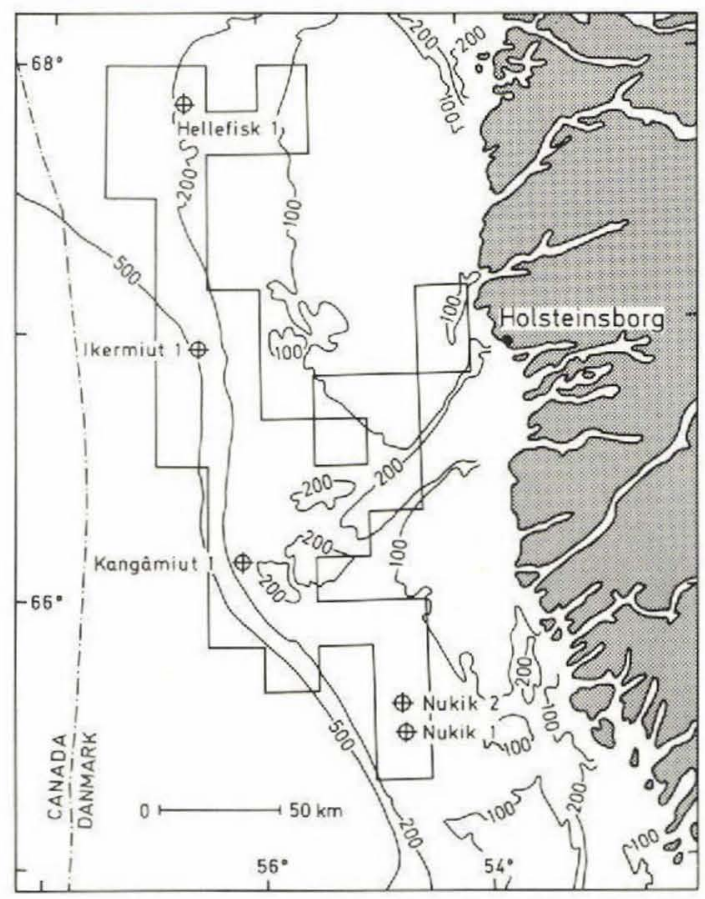

\section{Availability of seismic and other data}

In accordance with the terms under which the data were submitted to the Ministry for Greenland, some of the seismic data from surveys carried out before the grant of concessions in April 1975 have now been released from confidential status. Out of a total of $20000 \mathrm{~km}$

Table 2. List of wells drilled offshore West Greenland

\begin{tabular}{|c|c|c|c|c|}
\hline Well name & Group & Coordinates & Water depth & Well depth \\
\hline Kangâniut 1 & TGA-Grepco & $\begin{array}{l}66^{\circ} 09^{\prime} 00.92^{\prime \prime N} \\
56^{\circ} 11^{\prime} 24.28^{\prime \prime W}\end{array}$ & $180 \mathrm{~m}$ & $3874=$ \\
\hline Hellefisk 1 & ARCO & $\begin{array}{l}67^{\circ} 52^{\prime} 40.60^{\prime \prime} \mathrm{N} \\
56^{\circ} 44^{\prime} 20.98^{\prime \prime} \mathrm{N}\end{array}$ & $163 \mathrm{~m}$ & $3201 \mathrm{~m}$ \\
\hline Nukik 1 & Mobil & $\begin{array}{l}65^{\circ} 31^{\prime} 36.19^{\prime \prime N} \\
54^{\circ} 45^{\prime} 37.79^{\prime \prime}\end{array}$ & $104 \mathrm{~m}$ & $2363 \mathrm{~m}$ \\
\hline Ikermiut 1 & Chevron & $\begin{array}{l}66^{\circ} 56^{\prime} 11.66^{\prime \prime} \mathrm{N} \\
56^{\circ} 35^{\prime} 26.45^{\prime \prime} \mathrm{W}\end{array}$ & $447 \mathrm{a}$ & $3619 \mathrm{~m}$ \\
\hline Nukik 2 & Mobil & $\begin{array}{l}65^{\circ} 37^{\prime} 54.39^{\prime \prime N} \\
54^{\circ} 46^{\prime} 00.59^{\prime \prime N}\end{array}$ & $117 \mathrm{~m}$ & $2694 \mathrm{~m}$ \\
\hline
\end{tabular}

* below rotary table 


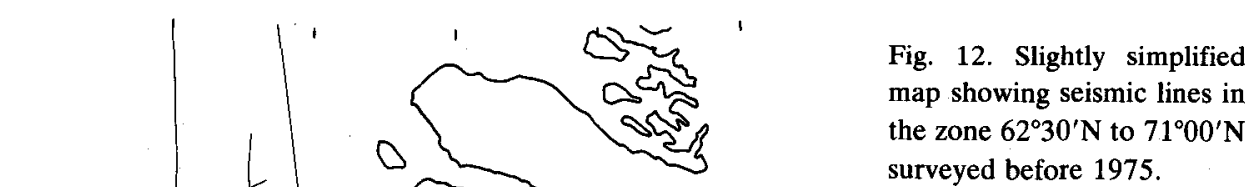

Fig. 12. Slightly simplified map showing seismic lines in surveyed before 1975 .

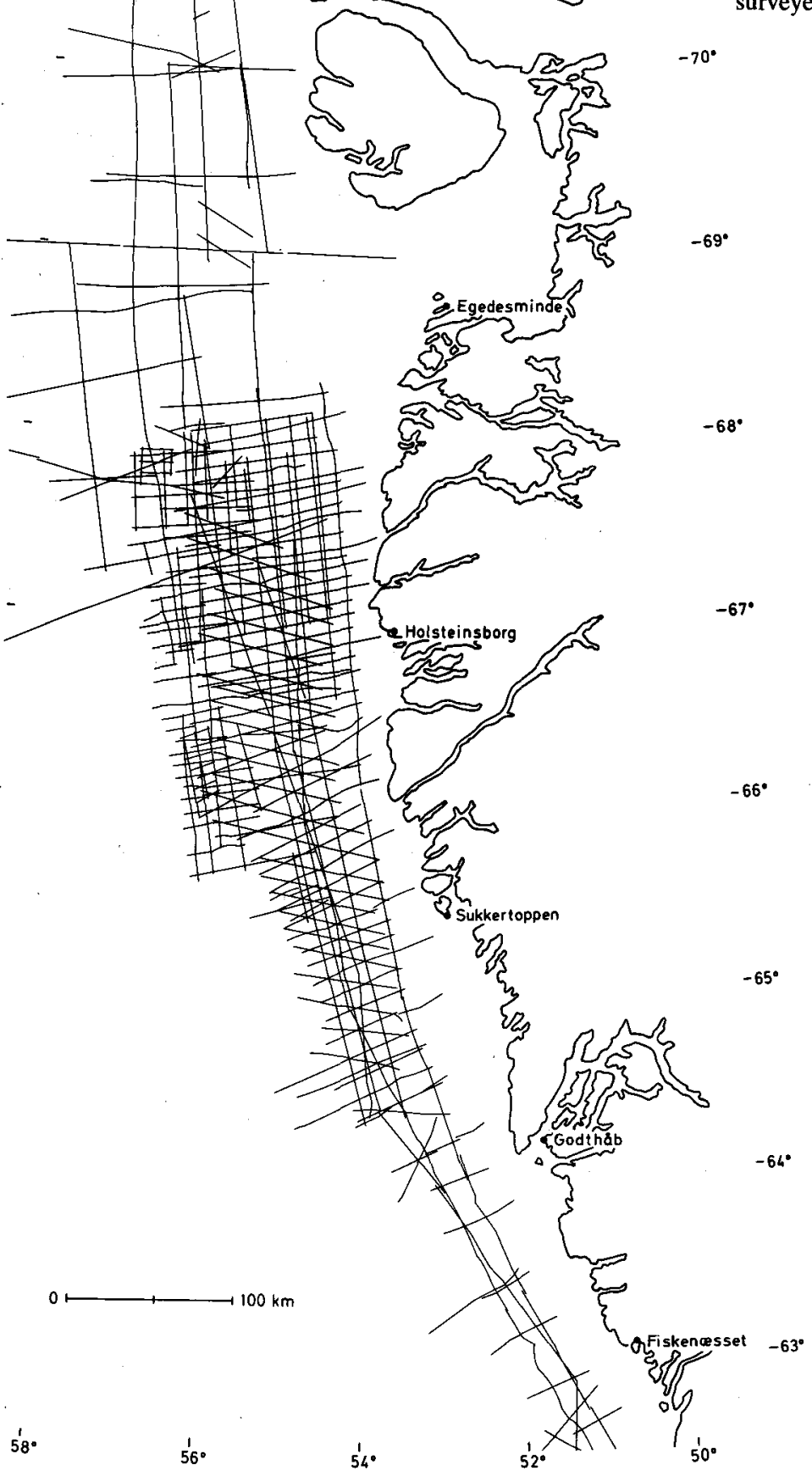


of seismic lines surveyed (fig. 12) nearly $6000 \mathrm{~km}$ are now available. These lines are sufficient to give a general picture of the depth to acoustic basement, the configuration of the acoustic basement and the structure of the sedimentary section in the area of the West Greenland shelf north of $64^{\circ} 30^{\prime} \mathrm{N}$. Marine magnetometer survey data are also available for some of the seismic lines.

One of the two regional aeromagnetic surveys from 1970 has now been released. This comprises $19000 \mathrm{~km}$ of lines covering the whole West Greenland shelf south of $72^{\circ} \mathrm{N}$.

All of the above-mentioned data are available for inspection in GGU. Most of the seismic lines have been photographed and paper dyeline copies are available for purchase. Details are available from the Survey on request.

General data from the Kangâmiut 1 well will be released from confidential status in August 1978. The first data from the 1977 wells will be available from the summer or autumn of 1979 .

\section{A brief geological assessment of the results to date}

Evaluation of the extensive seismic data acquired by the companies before the grant of concessions in April 1975 had already shown the presence of a sedimentary succession underlying large areas of the West Greenland continental shelf, including the zone between $65^{\circ} 20^{\prime}$ and $68^{\circ} 00^{\prime} \mathrm{N}$ which now contains most of the concessions, and that the succession was thick, locally up to $7 \mathrm{~km}$. The first precondition for continuing petroleum exploration had thus been met.

The seismic data also showed that there were a number of large structures in the region, particularly but not only in the western part of the main concession area, $100 \mathrm{~km}$ or more from the coast. These structures are mainly expressed by the top of the acoustic basement, but to some extent are also expressed by closure of the seismic depth contours some distance up in the sedimentary sequence.

GGU's investigations over the years of the Cretaceous - Lower Tertiary sedimentary sequence in the Disko-Nûgssuaq region had shown that the shales on land had a considerable content of organic material and that these shales to a certain extent were suitable as source rocks, mainly for gas (Henderson, 1976; Schiener, 1976). In addition, there are in the land area porous and permeable sandstones which could be good reservoir rocks. Even if the field mapping - combined with marine and airborne investigations - had shown that this land area constituted a local embayment separated from the extensive sedimentary basin to the west and south-west in part by a Precambrian gneiss ridge, in part by an area of Tertiary basalts, it was logical to assume that sedimentary rocks of similar type and age extended below the continental shelf. In addition, it was tempting to make comparisons with the Labrador shelf, where encouraging amounts of gas had been found in two wells drilled before 1975 .

About $15000 \mathrm{~km}$ of seismic lines have been shot since the spring of 1975 . With the exception of the southernmost concession area between $63^{\circ} 00^{\prime}$ and $63^{\circ} 30^{\prime} \mathrm{N}$, where the amount of seismic data available before 1975 was very little, the new seismic data have confirmed the earlier seismic mapping and provided more detail without altering the general configuration. 
Five wells have now been drilled and, as stated, all were dry holes. Two of these, Kangâmiut 1 and Ikermiut 1 had indications of gas. Even if the area contains thick sections of sedimentary rocks and even if there are a number of large structures which look promising on a seismic map, none of the wells to date have encountered the necessary combination of suitable source rocks and reservoir rocks, which are two fundamental preconditions for the presence of hydrocarbons in commercial quantities.

These five wells have provided a large number of samples and a wealth of new data. Almost $15000 \mathrm{~m}$ of hole has been drilled below the sea floor, logged and thoroughly sampled. GGU has received nearly 6000 samples of various types. Micropalaeontological and palynological studies are still in progress aimed at establishing the chronostratigraphy in the individual wells and the correlation between these, and with a view to providing information on the depositional environment. Geochemical studies of the organic content of the sediments are still in progress. As these results become available, the regional geology based on seismic interpretation has to be reexamined to see whether more promising prospects can be found.

However, it should be emphasised that the vital question is not whether there are petroleum occurrences in this region, but whether there are commercially exploitable occurrences. This is a high cost frontier region where the costs of extraction would make only the largest petroleum reservoirs commercially viable. The five dry wells to date have not improved the chances for there being such reservoirs in this region.

\section{References}

Henderson, G. 1976: Petroleum geology. In Escher, A. \& Watt, W. S. (edit.) Geology of Greenland, 488-505. Copenhagen: Geol. Surv. Greenland.

Schiener, E. J. 1976: Study of organic matter in Cretaceous-Tertiary sediments, central West Greenland. Rapp. Grønlands geol. Unders. 80, 43-49.

\section{Field work on the Precambrian of the Agto - Nordre Strømfjord area, central West Greenland}

\section{John A. Korstgård and Niels Ø. Olesen}

This was the penultimate season of the mapping programme initiated in 1975 with the aim of completing the Agto 1:100 000 map sheet (Olesen \& Sørensen, 1976).

In addition to the present writers the following students from Aarhus University participated in the mapping work: Flemming G. Christiansen, Flemming C. Mengel, Terkel S. Olsen, and Anders Rehkopff, assisted by Karen Marie P. Nielsen and Peter J. Jørgensen.

Support was provided by GGU motor boat Kornerup, skipper Absalon Jensen, and helicopter transport was shared with the GGU geophysical group working out of Søndre Strømfjord (see Secher \& Larsen; Thorning et al., this report). 